\title{
Detection of heterozygous MDRI nt230(del4) mutation in a mixed-breed dog: case report of possible doxorubicin toxicosis
}

This article was published in the following Dove Press journal:

Veterinary Medicine: Research and Reports

4 October 2013

Number of times this article has been viewed

\author{
Marina Mitie Monobe' \\ Kari V Lunsford ${ }^{2}$ \\ João Pessoa Araújo Jr ${ }^{3}$ \\ Camilo Bulla ${ }^{4}$ \\ 'Department of Veterinary Clinics, \\ School of Veterinary Medicine \\ and Animal Science, Sao Paulo \\ State University, Botucatu, Brazil; \\ ${ }^{2}$ Department of Clinical Sciences and \\ Animal Health Center, College of \\ Veterinary Medicine, Mississippi State \\ University, MS, USA; ${ }^{3}$ Department \\ of Microbiology and Immunology, \\ Biosciences Institute, Sao Paulo \\ State University, Botucatu, Brazil; \\ ${ }^{4}$ Department of Pathobiology \\ and Population Medicine, College of \\ Veterinary Medicine, Mississippi State \\ University, MS, USA
}

Abstract: P-glycoprotein (ABCB1), the product of the Multidrug Resistance Gene (MDR1) (ABCB1) gene, is the major multidrug transporter contributing to the barrier function of several tissues and organs, including the brain. A four base pair deletion mutation in MDR1 results in the absence of a functional form of $\mathrm{ABCB} 1$ and loss of its protective function. Severe intoxication with the $\mathrm{ABCB} 1$ substrate, such as with anticancer drugs, has been attributed to genetic lack of functional $\mathrm{ABCB} 1$. This mutation has been detected in more than 10 dog breeds as well as in mixed-breed dogs living in different countries. In Brazil, evaluation for this mutation is not as widely available and is rarely used by veterinarians, so drug intoxication may be underdiagnosed. This is the first report from Brazil of doxorubicin neurotoxicity in a mixed-breed dog with the MDR1 nt230(de14) mutation.

Keywords: canine, toxicology, cancer, P-glycoprotein

\section{Introduction}

The multidrug resistance (MDR) transporter P-glycoprotein (ABCB1) is the product of the MDR1 (ABCB1) gene and belongs to the family of membrane-bound ATPbinding cassette $(\mathrm{ABC})$ transporters. ${ }^{1}$ It is expressed in many tissues with secretory or excretory functions, including the liver (canalicular membrane of hepatocytes), kidney (luminal membrane of the proximal tubules), and intestine (brush border membrane of enterocytes), where it limits drug absorption from the gut and promotes drug excretion into the bile and urine. $\mathrm{ABCB} 1$ is also expressed at physiological barriers, where it acts as an important impediment to the distribution of substrate drugs to selected tissues and restricts passage of xenobiotics through the blood-brain barriers, the blood-testes barrier, and the placenta. ${ }^{2-4}$

In 2001, a mutation in the MDR1 gene was described in ivermectin-sensitive collies and identified as MDR1 nt230(del4). ${ }^{5}$ The mutation involves a frameshift deletion mutation that generates multiple premature stop codons, resulting in a severely truncated P-glycoprotein composed of $<10 \%$ of the wild-type amino acid sequence. ${ }^{6}$ This allele probably results in a complete loss of $\mathrm{ABCB} 1$ function.

Due to the nature of $\mathrm{ABCB} 1$ as an efflux pump to protect the cell against a wide variety of substances, $\mathrm{ABCB} 1$ substrates vary greatly in size, structure, and function. Substrates range from small molecules, such as organic cations, amino acids, and some antibiotics, to macromolecules, such as polysaccharides and proteins. ${ }^{7}$ These substrates include multiple hydrophobic and amphipathic drugs, many of which are commonly used in veterinary medicine. ${ }^{8-14}$ (Table 1). Because ABCB1 has an important role in drug pharmacokinetics, related mutations that result in reduced expression lead to 
Table I Substrates for P-glycoprotein

\begin{tabular}{l} 
Anticancer drugs \\
Doxorubicin \\
Vincristine \\
Vinblastine \\
Immunosuppressants \\
Ciclosporin \\
Antiparasitic drugs \\
Ivermectin \\
Moxidectin \\
Steroid hormones \\
Aldosterone \\
Cortisol \\
Dexamethasone \\
Antimicrobial agents \\
Tetracycline \\
Doxycycline \\
Levofloxacin \\
Ketoconazole \\
Itraconazole \\
Analgesics \\
Morphine \\
Methadone \\
Antidiarrheals \\
Loperamide \\
Anticonvulsants \\
Phenothiazine \\
Cardiac drugs \\
Digoxin \\
Diltiazem \\
Verapamil \\
Talinolol \\
\hline
\end{tabular}

increased oral bioavailability and reduced elimination via the liver, kidney, and intestines. ${ }^{15,16}$ However, the most dramatic clinical consequences of impaired ABCB1 function are the neurotoxic effects described since 1983 in cases of ivermectin toxicosis in collies. ${ }^{17,18} \mathrm{Clinical}$ signs of neurotoxicity include mydriasis, stupor, lethargy, vomiting, ataxia, tremors, ptyalism, coma, blindness, convulsion, and death. ${ }^{19-21}$ Little is known about the effects of these substances in dogs that are heterozygous for the mutation, but the recommendation has been made that heterozygous dogs should be treated with caution when using drugs that are known $\mathrm{ABCB} 1$ substrates (http://www.vetmed.wsu.edu/depts-vcpl/drugs.aspx).

\section{Case report}

In 2011, a blood sample from an eight-year-old female mixedbreed dog was sent to our laboratory for MDR1 mutation testing. The animal had been diagnosed with lymphoma two months previously and was started on a chemotherapeutic protocol containing cyclophosphamide, doxorubicin, vincristine, and prednisolone (Table 2). During the first administration of doxorubicin ( $30 \mathrm{mg} / \mathrm{m}^{3}$ by slow intravenous push) the
Table 2 Chemotherapeutic treatments and clinical responses in an eight-year old, female, mixed-breed dog with lymphoma and the MDRI deletion mutation (heterozygous genotype) associated with ivermectin sensitivity

\begin{tabular}{|c|c|c|}
\hline $\begin{array}{l}\text { Treatment } \\
\text { week }\end{array}$ & Drugs administered & Toxic effects \\
\hline I & $\begin{array}{l}\text { Vincristine }\left(0.5 \mathrm{mg} / \mathrm{m}^{2} \mathrm{IV}\right) \\
\text { L-asparaginase } \\
(400 \mathrm{Ul} / \mathrm{kg} \mathrm{SC}) \\
\text { Prednisone }(2 \mathrm{mg} / \mathrm{kg} \mathrm{PO} \text {, } \\
\text { q } 24 \mathrm{~h})\end{array}$ & $\begin{array}{l}\text { Thrombocytopenia } \\
\text { (140,000 platelets } / \mu \mathrm{L})\end{array}$ \\
\hline 2 & $\begin{array}{l}\text { Cyclophosphamide } \\
\left(200 \mathrm{mg} / \mathrm{m}^{2} \mathrm{IV}\right) \\
\text { Prednisone }(1.5 \mathrm{mg} / \mathrm{kg} \mathrm{PO} \text {, } \\
\text { q } 24 \mathrm{~h})\end{array}$ & $\begin{array}{l}\text { Polyuria, polydipsia, loss } \\
\text { of weight }\end{array}$ \\
\hline 3 & $\begin{array}{l}\text { Vincristine }\left(0.5 \mathrm{mg} / \mathrm{m}^{2} \mathrm{IV}\right) \\
\text { Prednisone }(\mathrm{I} \mathrm{mg} / \mathrm{kg} \text { PO, } \\
\text { q } 24 \mathrm{~h})\end{array}$ & None \\
\hline 4 & $\begin{array}{l}\text { Doxorubicin }\left(30 \mathrm{mg} / \mathrm{m}^{2} \mathrm{IV}\right) \\
\text { Prednisone }(0.5 \mathrm{mg} / \mathrm{kg} \mathrm{PO} \text {, } \\
\text { q } 24 \mathrm{~h})\end{array}$ & $\begin{array}{l}\text { Salivation, tachypnea } \\
\text { (60 breaths/min), } \\
\text { tachycardia (160 bpm), } \\
\text { depression and ataxia }\end{array}$ \\
\hline $\begin{array}{l}5 \\
6 \\
7\end{array}$ & $\begin{array}{l}\text { None } \\
\text { Vincristine }\left(0.5 \mathrm{mg} / \mathrm{m}^{2} \mathrm{IV}\right) \\
\text { Cyclophosphamide }\end{array}$ & $\begin{array}{l}\text { None } \\
\text { Vomiting, loss of appetite } \\
\text { Neutropenia }\end{array}$ \\
\hline $\begin{array}{l}8 \\
9\end{array}$ & $\begin{array}{l}\left(200 \mathrm{mg} / \mathrm{m}^{2} \mathrm{IV}\right) \\
\text { Vincristine }\left(0.5 \mathrm{mg} / \mathrm{m}^{2} \mathrm{IV}\right) \\
\text { Doxorubicin }\left(30 \mathrm{mg} / \mathrm{m}^{2} \mathrm{IV}\right)\end{array}$ & $\begin{array}{l}(2,500 \text { cells } / \mu L) \\
\text { Vomiting } \\
\text { Loss of consciousness, }\end{array}$ \\
\hline & $\begin{array}{l}\text { Phenobarbital }(6 \mathrm{mg} / \mathrm{kg} \text { IM) } \\
\text { Diazepam }(0.5 \mathrm{mg} / \mathrm{kg})\end{array}$ & $\begin{array}{l}\text { tachycardia }(180 \mathrm{bpm}) \text {, } \\
\text { tremors and convulsions, } \\
\text { fever }\left(39.8^{\circ} \mathrm{C}\right) \text {, } \\
\text { thrombocytopenia } \\
(78,000 \text { platelets } / \mu \mathrm{L})\end{array}$ \\
\hline 10 & Stopped treatment & None \\
\hline
\end{tabular}

Abbreviations: MDR, multidrug resistance gene; PO, per oral; SC, subcutaneous; IM, intramuscular; IV, intraavenous.

patient showed unusual clinical signs, including salivation, tachypnea ( 60 breaths per minute), tachycardia (160 beats per minute), depression, and ataxia, but these signs resolved within 24 hours. The attending veterinarian believed that these clinical signs were related to advanced disease and elected to proceed with the planned protocol. However, the clinical signs recurred with increased intensity four weeks later following the next dose of doxorubicin. This time, the dog suffered from loss of consciousness, tachycardia, tremors, and convulsions. Under these circumstances, the veterinarian administered anticonvulsive doses of rectal diazepam, but the dog failed to respond to it but did respond when he administered phenobarbital (6 mg/kg IM). Following administration of phenobarbital, the convulsions ceased and the dog regained consciousness. On physical examination, the dog was febrile $\left(39.8^{\circ} \mathrm{C}\right)$ and weak. Hematological analysis (complete blood count, white cell count), urinalysis, serum biochemical analysis, and ultrasonography were performed and the only abnormality present was thrombocytopenia 
(78,000 platelets $/ \mu \mathrm{L})$. The veterinarian discontinued chemotherapy and although the dog did not have the collie phenotype, he suspected efflux pump dysfunction when the owner reported similar neurological clinical signs following administration of moxidectin.

To perform the diagnostic test, we used an allele-specificbased screening method. Briefly, DNA was extracted directly from a $330 \mu \mathrm{L}$ blood sample using the Illustra Blood Genomic Prep Mini Spin Kit (GE Healthcare, Chalfont, UK) and following the manufacturer's recommended protocol. Approximately $100 \mathrm{ng}$ of DNA was used for PCR amplification. Allele-specific PCR was performed as described elsewhere, using positive and negative controls ${ }^{22}$ and with primers $\mathrm{ABCB} 1 \mathrm{~A}, \mathrm{ABCB} 1 \mathrm{~B}, \mathrm{ABCB} 1 \mathrm{C}$, and $\mathrm{ABCB} 1 \mathrm{D}$. The primers were designed to allow detection of the wild-type MDR1 allele by PCR1 (ABCB1A, ABCB1B, and $A B C B 1 D)$ and detection of the mutant MDR1 allele by PCR2 (ABCB1A, ABCB1C, and ABCB1D). An amplicon with 326 base pairs is generated only if $\mathrm{ABCB} 1 \mathrm{~B}$ matches the wild-type allele in PCR1 or if $\mathrm{ABCB} 1 \mathrm{C}$ matches the mutant allele in PCR2. Independent of the presence or absence of the four base pair deletion, an additional control amplicon with approximately 480 base pairs was obtained with the ABCB1A and ABCB1D primer pair in both reactions (Figure 1). Sequencing analysis was used to confirm heterozygosity in this case.

Although the effect of the heterozygous condition in the dog has not been evaluated, the clinical recommendation has been made to exercise caution when administering drugs like doxorubicin to dogs heterozygous for the MDR1 mutation. ${ }^{8}$ Studies in other species have demonstrated that P-glycoprotein function is intermediate in heterozygotes. Flow cytometric rhodamine efflux studies ${ }^{24}$ in peripheral blood mononuclear cells in vitro and tacrolimus pharmacokinetic studies in renal transplant patients ${ }^{25}$ have shown

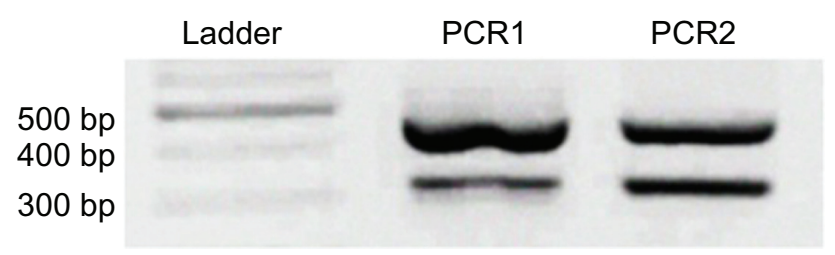

Figure I Results of allele-specific PCR testing in an eight-year old, female, mixedbreed dog with heterozygous MDRI genotype. PCRI refers to wild type allele detection and PCR2 refers to MDRI mutant allele detection. An amplicon with 326 bp is generated only if ABCBIB matches the wild type allele in PCRI or if $A B C B I C$ matches the mutant allele in PCR2. Independent of the presence or absence of the 4 bp deletion, an additional control amplicon with $\approx 480$ bp was obtained with primer pair $A B C B I A$ and $A B C B I D$ in both reactions.

Abbreviations: bp, blood pressure; $P C R$, polymerase chain reaction; $M D R$, multidrug resistance gene. that MDR1 mutation heterozygotes have intermediately functional P-glycoprotein. The recommendation for heterozygous dogs receiving doxorubicin is a $25 \%$ reduction in dose (http://www.vetmed.wsu.edu/depts-vcpl/drugs.aspx). While it would be expected that a dog with reduced P-glycoprotein expression would have heightened susceptibility to commonly seen drug side effects, such as myelosuppression and adverse gastrointestinal reactions, it is possible that doxorubicin might cause acute neurotoxicity because it has been shown to be neurotoxic when the blood-brain barrier is breached in dogs. ${ }^{26}$

The MDR1 nt230(del4) mutation is an inherited trait and genetic screening is important both for gene pools and for individual patients. ${ }^{27,28}$ Recent genetic screening studies performed in several dog breeds identified the mutation not only in collies, but also in more than $10 \mathrm{dog}$ breeds as well as mixed-breed dogs. ${ }^{29-32}$ After identification of the MDR1 nt230(del4), several molecular techniques were developed for use as diagnostic screening tools and have been successfully used in at-risk breeds prior to application of therapeutic protocols involving known ABCB1 substrates. Unfortunately, in Brazil, the screening methods have only recently been made commercially available and are underutilized, so it is likely that many historical cases of intoxication have gone unrecognized. In this case, the patient had unusual signs following two administrations of doxorubicin, leading the owner to report similar signs following administration of moxidectin. Moxidectin is a drug known to produce neurotoxicity in dogs deficient in ABCB1 activity. This case illustrates the potential for heightened susceptibility to toxicity in dogs with heterozygous MDR1 mutation and demonstrates the need for further pharmacogenetic investigation in populations and also in individual animals.

\section{Conclusion}

This is the first case report from Brazil of a dog suffering from drug intoxication, potentially as the result of a dysfunctional efflux pump. It is of particular interest that this dog was not a collie-related breed and was found to be heterozygous for the mutation, so it is quite possible that dogs displaying unusual neurotoxicity following administration of a known ABCB1 substrate drug may in fact carry the mutation. Genetic screening of dogs for this mutation prior to the administration of known substrates will allow dose reduction or alternative treatment choices to be made and will significantly reduce morbidity in affected animals. 


\section{Acknowledgment}

The authors thank the veterinarians who contributed to this research by providing blood samples and case information about the animal involved.

\section{Disclosure}

None of the authors have any financial or personal relationship that could inappropriately influence or bias the content of the paper.

\section{References}

1. Dean M, Rzhetsky A, Allikmets R. The human ATP-binding cassette (ABC) transporter superfamily. Genome Res. 2001;11:1156-1166.

2. Cordon-Cardo C, O'Brien LP, Boccia J, et al. Expression of the multidrug resistance gene product (P-glycoprotein) in human normal and tumor tissues. J Histochem Cytochem. 1990;38:1277-1287.

3. Chaudhary PM, Roninson IB. Expression and activity of P glycoprotein, a multidrug efflux pump, in human hematopoietic stem cells. Cell. 1991;66:85-94.

4. Thiebaut F, Tsuruo H, Hamada H, et al. Cellular localization of the multidrug-resistance gene product P-glycoprotein in normal human tissues. Proc Natl Acad Sci U S A. 1987;84:7735-7738.

5. Mealey KL, Bentjen SA, Gay JM, et al. Ivermectin sensitivity in collies is associated with a deletion mutation of the mdr1 gene. Pharmacogenetics. 2001;11:727-733.

6. Roulet A, Puel O, Gesta S, et al. MDR1-deficient genotype in Collie dogs hypersensitive to the P-glycoprotein substrate ivermectin. Eur J Pharmacol. 2003;460:85-91.

7. Zhou SF. Structure, function and regulation of P-glycoprotein and its clinical relevance in drug disposition. Xenobiotica. 2008;38: 802-832.

8. Dowling P. Pharmacogenetics: it's not just about ivermectin in collies. Can Vet J. 2006;47:1165-1168.

9. Erkens T, Daminet S, Rogiers C, et al. Presence of the ABCB1 (mdr1) deletion mutation causing ivermectin hypersensitivity in certain dog breeds in Belgium. Vlaams Diergeneeskundig Tijdschrift. 2009;78: 256-260.

10. Fromm FM. Importance of P-glycoprotein at blood-tissue barriers. Trends Pharmacol Sci. 2004;25:423-429.

11. Geyer J, Döring B, Godoy JR, et al. Frequency of the nt230 (del4) MDR1 mutation in Collies and related dog breeds in Germany. $J$ Vet Pharmacol Ther. 2005;28:545-551.

12. Martinez M, Modric S, Sharkey M, et al. The pharmacogenomics of P-glycoprotein and its role in veterinary medicine. $J$ Vet Pharmacol Ther. 2008;31:285-300.

13. Mealey KL. Therapeutic implications of the mdr-1 gene. J Vet Pharmacol Ther. 2004;27:257-264.

14. Mealey KL, Bentjen SA, Waiting DK. Frequency of the mutant MDR1 allele associated with ivermectin sensitivity in a sample population of Collies from the northwestern United States. Am J Vet Res. 2002;63: $479-481$.
15. Mealey KL, Munyard KA, Bentjen SA. Frequency of the mutant MDR1 allele associated with multidrug sensitivity in a sample of herding breed dogs living in Australia. Vet Parasitol. 2005;131:193-196.

16. Panwala CM, Jones JC, Viney JL. A novel model of inflammatory bowel disease: mice deficient for the multiple drug resistance gene, MDR1a, spontaneously develop colitis. J Immunol. 1998;161:5733-5744.

17. Schinkel AH, Smit JJ, Van Tellingen O, et al. Disruption of the mouse mdr1a P-glycoprotein gene leads to a deficiency in the blood-brain barrier and to 3 increased sensitivity to drugs. Cell. 1994;77:491-502.

18. Seward RL. Reactions in dogs given ivermectin. J Am Vet Med Assoc. 1983;183:493.

19. Barbet JL, Snook T, Gay JM, et al. ABCB1-1 Delta (MDR1-1 Delta) genotype is associated with adverse reactions in dogs treated with milbemycin oxime for generalized demodicosis. Vet Dermatol. 2009;20: $111-114$.

20. Geyer J, Klintzsch S, Meerkamp K, et al. Detection of the nt230(de14) MDR1 mutation in White Swiss Shepherd dogs: case reports of doramectin toxicosis, breed predisposition, and microsatellite analysis. J Vet Pharmacol Ther. 2007;30:482-485.

21. Pulliam JD, Seward RL, Henry RT, et al. Investigating ivermectin toxicity in Collies. Vet Med. 1985;80:36-40.

22. Baars C, Leeb T, Von Klopmann T, et al. Allele-specific polymerase chain reaction diagnostic test for the functional MDR1 polymorphism in dogs. Vet J. 2008;177:394-397.

23. Hitzil M, Drescher S, Van Der Kuip H, et al. The C3435T mutation in the human MDR1 gene is associated with altered efflux of the P-glycoprotein substrate rhodamine 123 from CD56+ natural killer cells. Pharmacogenetics. 2001;11:293-298.

24. Mealey KL, Meurs KM. Breed distribution of the ABCB1-1delta (multidrug sensitivity) polymorphism among dogs undergoing ABCB1 genotyping. J Am Vet Med Assoc. 2008;233:921-924.

25. Utecht KN, Hiles JJ, Kolesar J. Effects of genetic polymorphisms on the pharmacokinetics of calcineurin inhibitors. Am J Health Syst Pharm. 2006;63:2340-2348.

26. Neuwelt EA, Glasberg M, Frenkel E, et al. Neurotoxicity of chemotherapeutic agents after blood-brain barrier modification: neuropathological studies. Ann Neurol. 1983;14:316-324.

27. Neff MW, Robertson KR, Wong AK, et al. Breed distribution and history of canine mdr1-1delta, a pharmacogenetic mutation that marks the emergence of breeds from the collie lineage. Proc Natl Acad Sci USA. 2004;101:11725-11730.

28. Padgett GA. Control of Canine Genetic Diseases, 1st ed. New York, NY: Howell Book House; 1998.

29. Gramer I, Leidolf R, Döring B, et al. Breed distribution of the nt230(del4) MDR1 mutation in dogs. Vet J. 2011;189:67-71.

30. Hugnet C, Bentjen SA, Mealey KL. Frequency of the mutant MDR1 allele associated with multidrug sensitivity in a sample of collies from France. J Vet Pharmacol Ther. 2004;27:227-229.

31. Kawabata A, Momoi Y, Inoue-Murayama M, et al. Canine mdr1 gene mutation in Japan. J Vet Med Sci. 2005;67:1103-1107.

32. Klintzsch S, Meerkamp K, Döring B, et al. Detection of the nt230[del4] MDR1 mutation in dogs by a fluorogenic 50 nuclease TaqMan allelic discrimination method. Vet J. 2010;185:272-277.
Veterinary Medicine: Research and Reports

\section{Publish your work in this journal}

Veterinary Medicine: Research and Reports is an international, peer-reviewed, open access journal publishing original research, case reports, editorials, reviews and commentaries on all areas of veterinary medicine. The manuscript management system is completely online and includes a very quick and fair peer-review system.

\section{Dovepress}

Visit http://www.dovepress.com/testimonials.php to read real quotes from published authors. 